\title{
Membership Distribution Becomes a Reality
}

It is with a sense of great satisfaction that this issue is sent to all members of ACRL except those in the $\$ 3.00$ ALA membership bracket. Former subscribers to our official journal, who now receive it as a membership prerequisite, will appreciate the personal saving as well as the usefulness of this long discussed step. Those who receive their own copies for the first time will benefit from the leisurely study and reference use which come with personal ownership. Nonmember subscribers number more than six hundred. Their support is important, and they are counted informally in the ACRL family. Also significant in another way are 85 libraries in 35 foreign countries which have complimentary subscriptions. At one stroke College and Research Libraries circulation is doubled. I hope its usefulness is doubled as well.

Membership distribution of the journal has been a chief Association goal for many years, and it is hoped that the distribution beginning with this issue is not a temporary achievement. Let no one think his increased ALA dues have made this possible. While the divisions hope that increased ALA income will be shared, the dues increases have complicated the problem by cutting into divisional income. In short, the ACRL Board of Directors decided to go ahead with this project in spite of the rise in ALA dues.

Advertising income is important, and $\mathrm{Col}$ lege and Research Libraries charges have been nearly doubled because of circulation increases. In spite of this many of our ad- vertising supporters of long standing are represented in this issue, particularly Stechert-Hafner, Virginia Metal Products Corporation, Remington Rand, Hertzberg Craftsmen, Funk and Wagnalls, and the New York Times. Former advertisers include the H. W. Wilson Co., Edwards Brothers, Columbia University Press, the Encyclopedia Americana, Abrahams Magazine Service, and Scarecrow Press, that useful part time activity of our own Ralph Shaw. Among those new to these pages are University Microfilms, F. W. Faxon and A. N. Marquis, honored and familiar names to all librarians. The advertisements reflect interest in problems and needs of college libraries and a desire to cooperate in professional activities. A little thoughtfulness on the part of readers in showing a reciprocal interêst will do a world of good.

This larger distribution of the journal is only one of several major steps whereby this Association expects to reach directly the professional life and activity of all its individual members. The establishment of ACRL chapters and our new system of state representatives are directed toward this same goal. In all plans a key factor is the economical distribution of a high quality journal. The interest and support of all librarians of good will are important. Only that interest and support, and no vote of any board, will determine whether membership distribution of College and Research Libraries becomes permanent as an activity of ACRL.-Arthur T. Hamlin, Executive Secretary. 